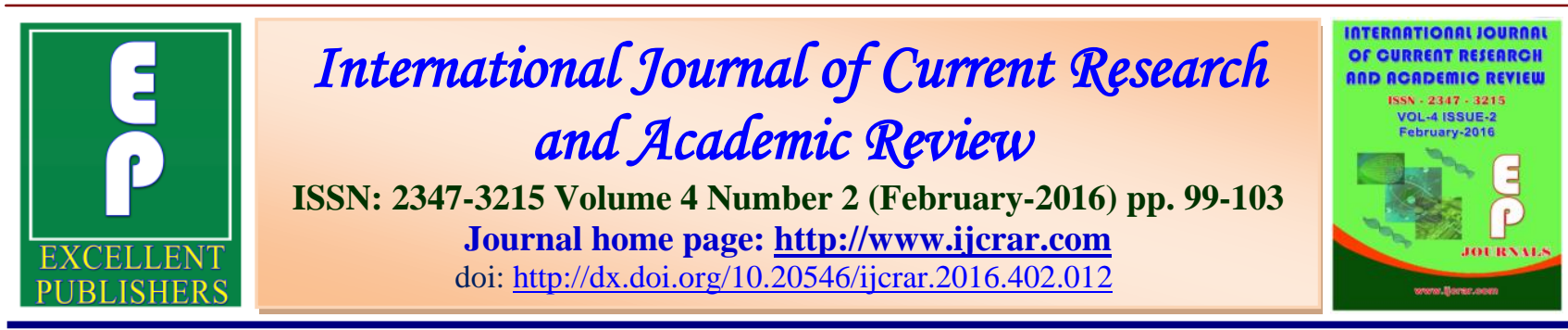

\title{
Measuring Oxidative Balance for Athletes Body building abusers Nutritional Supplements in the City of Kirkuk, Iraq
}

\author{
Zainab A. Hassan* \\ Department of Pathological Analysis, Technical Institute, Hawija, Kirkuk, Iraq \\ *Corresponding author
}

\begin{tabular}{|c|c|}
\hline KEYWORDS & A B S T R A C T \\
\hline $\begin{array}{l}\text { Oxidative } \\
\text { balance, } \\
\text { Athletes, } \\
\text { Nutritional } \\
\text { supplements }\end{array}$ & $\begin{array}{l}\text { Research was conducted on (100) athletes from play these sports in sport's } \\
\text { halls in the city of Kirkuk and abusers nutritional supplements within a period } \\
\text { ranging from } 6 \text { months to } 3 \text { years and within the age group } 20-40 \text { years. Has } \\
\text { been confirmed not to have chronic diseases were measured oxidative balance } \\
\text { by measuring the level of Malondialdehid (MDA) as a measure of free radical } \\
\text { in serum and measure the level of Glutathione (GSH) as a measure of } \\
\text { antioxidants in the blood serum The results were compared with (50) young } \\
\text { man in the same age group } 20-40 \text { years practitioners of the sport and non- } \\
\text { abusers nutritional supplements as a group control. Our study showed } \\
\text { increase significant in ( } \mathrm{P} \leq 0.01) \text { in the level of serum Malondialdehid MDA } \\
\text { group of athletes compared to the control group. It also showed the presence } \\
\text { of a significant decrease in the level of serum Glutathione GSH group of } \\
\text { athletes compared to the control group. }\end{array}$ \\
\hline
\end{tabular}

\section{Introduction}

Body cells need oxygen to produce energy and oxygen that reacts with the digested food particles as it produces carbon dioxide, water and energy, During this interaction some free radicals are graduated negatively charged particles containing a single electron in the outer casing and free radicals are unstable and react quickly with other compounds for the electron to fill the outer casing and access to the state of stability, But that did not get to settle Electron will start a chain reaction that may end up in a living cell destruction. (1)Where interactive effect of concentrated oxygen radicals of DNA damage and oxidation of fats, amino acids and enzymes to destroy anti-oxidants, Thus, they cause many diseases including cancer, Alzheimer's, heart disease, kidney disease and other (2), (3). Be disposed of free radicals in our body, which is made up through antioxidants that work to interact with them and to stop the chain reactions of these radicals before they damage living 
cells, including antioxidants in our body is made up naturally and be divided into:

Enzymatic systems: Superoxide dismutase (SOD), glutathione reductase, thioredoxin.

Non-enzymatic systems: uric acid, glutathione GSH, zinc, selenium.

Vitamins from outside the body the most important of vitamin E, C, A.(4)

In addition to the harmful effects of free radicals, the vitality of its benefits, they play an important role in immune reactions toxic to bacteria and the destruction of strange bodies and kill cancer cells and stimulate or suppress genes and infection control and protect the brain and control the constriction of blood vessels and the nervous Transportation, In other words, free radicals are useful as long as the concentrations of antioxidants were higher concentrations of free radicals(5).

That sport is important for our health, is no secret to one of the enormous benefits that it is possible to get it by the exercise, In all areas, including psychological, such as the disposal of tension and anxiety, and somatic treatment such as lowering cholesterol and blood sugar and preventive such as activation of the immune system. However, when exercising violent body is exposed to high muscular effort, especially in bodybuilding exercises, which should be the body accommodate this effort through some adaptations such as increase the activity of surrounding cells and blood vessels to produce nitric oxide NO, it is One of the types of free radicals that relax and expansion the walls of blood vessels, which reduces the pressure inside the blood vessels as well as he would work to increase the size of the blood vessels leads the largest amount of processing of blood to the muscles(6). and activate the platelets and the transfer of cellular signals. (7)Also, the violent sport that requires bodybuilding lead to oxygen consumption and speed, causing the reduction of oxygen to be incomplete that lead to increase the proportion of free radicals within the body of athletes such as hydroxyl radical, $\bullet \mathrm{OH}$, super oxide and hydrogen peroxide and malondialdehyde (MDA) radical(8).

We have noted in recent young people went to practice the sport of bodybuilding and convergence increased use of nutritional supplements without medical supervision for get sports bodies in a short period of time and in the forefront of these supplements are proteins that produce free radicals when metabolism (9), (10). In addition to the use a certain amino acids such as arginine which turns into nitric oxide NO which turns in the kidneys to nitric oxide. (11) It means exposing the body extra high concentration of free radicals and the negligence of the body cleaning by antioxidants as a result of ignorance and unconscious halls for training and charge of them.

The purpose of this study to measure the oxidative balance for athletes in bodybuilding by measuring the level of malondialdehyde (MDA) as a measure of free radical in serum and measure the level of glutathione as a measure of antioxidants in the blood serum.

\section{Materials and Methods}

\section{Collection of Blood Sample}

Were collected 100 blood samples from athletes attending sports halls for bodybuilding drug users and nutritional supplements for the period from 15.02.2015 to 15.04.2015 within the age group 20-40 years. The results were compared with blood samples from 50 healthy young Practitioners of the sport and non-abusers nutritional supplements within the same age group. 
Were withdrawn $(5 \mathrm{~cm} 3)$ of the venous blood using a syringe size $(5 \mathrm{~cm} 3)$ and put the blood in a plastic test tubes with covers court and free of anti-clotting substancesAnd left blood at a temperature of $25^{\circ} \mathrm{C}$ until clotting then separated serum using centrifuge quickly and $3000 \mathrm{c} / \mathrm{min}$ and then was withdrawn serum using micro Pipette for the purpose of obtaining serum.

\section{Tests}

Conducted tests to measure the concentration of malondialdehyde (MDA) in serum as an indicator of the concentration of free radicals and measure the concentration of glutathione in serum as an indicator of the concentration of antioxidants. Almalondayaldehid is the final product lipid peroxidation that interact with (TBA) thiobarbituric acid and gets this reaction in acidic medium and the output of colored and measured the intensity of absorption at (532) $\mathrm{nm}$ (12). it was estimatedglutathione in serum by using the modified method used by the researchers.(13)

Method depends on the use of Ellman's reagent containing the DTNB (5,5-dithiobisNitrobenzoic acid), which reduces mediated with glutathione thiol group to produce a yellow color compound is read absorbance at $412 \mathrm{~nm}$.

\section{Statistical Analysis}

Results were analyzed according to T-test.

\section{Result and Discussion}

Shown in Figure (1) there is Significant increase in the level of malondialdehyde MDA serum for a group of athletes at the Significant level $(\mathrm{P} \leq 0.01)$ at a rate of $(2.560$ \pm 0.802 ) $\mu \mathrm{mol} / \mathrm{L}$ compared to the control group and the rate of $(0.967 \pm 0.626) \mu \mathrm{mol} /$ L. Our results are consistent with the (14) (15) that the high malondialdehyde (MDA)level of reason to high fat oxidation by free radicals.

Shown in Figure (2) there is a significant decrease in the level of serum glutathione in athletes group at a rate of $(2.712 \pm 0.496)$ $\mu \mathrm{mol} / \mathrm{L}$ compared to the control group and the rate of $(4.358 \pm 0.433) \mu \mathrm{mol} / \mathrm{L}$. Our results are consistent with each of the (16) (17) It pointed out thatglutathione is one of the most important non-enzymatic antioxidants, which works to remove free radicals and its products, And that the level of the reduced form of glutathione in cells and tissues to be higher than the oxidized form his (GSSG).

Figure.1 Shows the Level of Malondialdehyde (Mda) in the Blood Serum of the Groups Studied

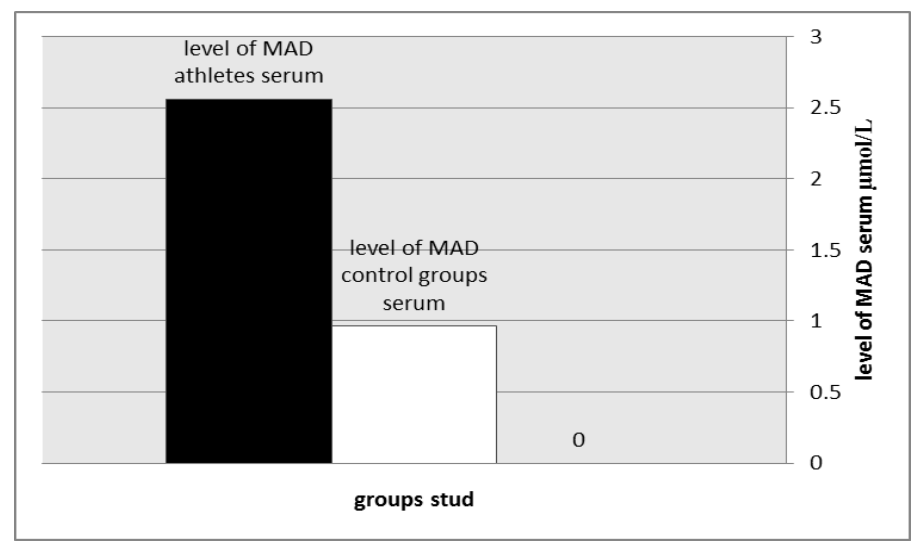


Figure.2 Shows the Level of Glutathione Blood Serum of the Studied Groups

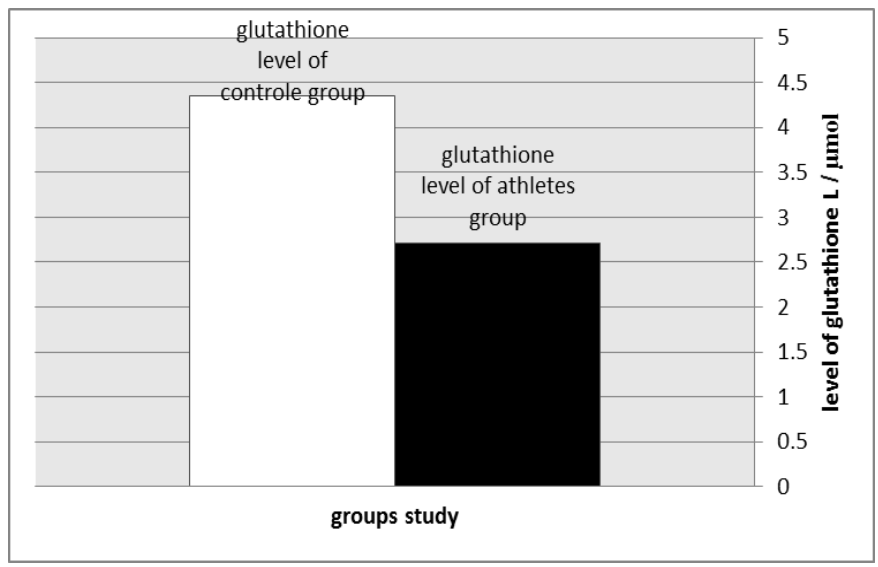

Thus, the ratio of reduced glutathione and oxidized glutathione(GSH / GSSG) are high,It is preservation of this ratio by a mechanism working on Reduction oxygenated form (GSSG) and turn it into a form of reduced $\mathrm{GSH}$, which controlled enzyme glutathione reductase.

\section{Conclusion}

Study showed oxidative balance deviation toward the balance of free radicals that have been expressed by measuring the level of malondialdehyde (MDA). We believe that this increase emergence of several factors, including:

The excessive violent exercise without scientific oversight, and that the managers of these sports halls are not with scientific expertise. The use of nutritional supplementation, protein, fatty and hormonal drugs and some contained pork fat and other materials unknown source we can not know the components of the difficulty of dealing with her abusers and use these substances are unsupervised and doses is not studied, which weighing the body producing substances radicals of cancer may not be able to treatment and disposal, especially that diets adopted by these athletes are almost free of natural antioxidants such as fruits and natural juices.

The sports hall itself does not apply to the health conditions of the area where compatibility with a number of athletes and the most important is the lack of adequate ventilation to provide enough oxygen for the hall, We have noticed in most halls and a large number of athletes engaged in violent sports that you need to provide the body with large amounts of oxygen in the halls with a small size and in an atmosphere almost stifling as a result of lack of oxygen.

\section{References}

1.R.T. Oakley, (1998). Cyclopentadienyl chromiumComplexesof1,2,3,5- Dithiadi azolyls: $\eta 2 \pi$ Complexes of Cyclic Sulfur-Nitrogen Compounds., Prog. Inorg. Chem., 36, 299.

2.P. Pacher, J. S. Beckman, L. Liaudet, (2007). Nitric oxide and peroxynitrite in health and disease. Physiol. Rev. 87 (1): 315-424.

3.Taylor and Francis. (2000) Toxicology of the Human Environment - the critical role of free radicals, London.

4.H. Sies (1996). Antioxidants in Disease, Mechanisms and Therapy, Academic Press, New York. 
5.A.D. Sarma, A.R Mallick, and A. K. Ghosh.(2010). Free Radicals and Their Role in Different Clinical Conditions: An Overview. International Journal of Pharma Sciences and Research (IJPSR)Vol.1(3), 185-192.

6.O. K. Baskurt, P Ulker., H. J. Meiselman, (2011). Nitric oxide, erythrocytes and exercise. Clinical hemorheology and microcirculation, 49, 175-181.

7.T.J, Guzik. N.E, West. R, Pillai. D.P, Taggart. K.M, Channon. (2002). "Nitric oxide modulates superoxide release and peroxynitrite formation in human blood vessels". Hypertension 39 (6): 1088-94.

8.T. Kobayashi, (2008) New primary Cancer Prevention methods of Risk Assessment Using a Tumor Combinition Assay/ HOLISTIC Keilloku Hospital, Tokyo, JAPA.

9.W.K.. Alderton, C.E, Cooper and R.G. Knowles (2001). Nitricoxide synthases structure, function and inhibition. Biochem. J. 357, 593-615.

10.A.C, Montezano and,R.M. Touyz (2011).Reactive Oxygen Species and Endothelial Function - Role of Nitric Oxide Synthase Uncoupling and Nox Family Nicotinamide Adenine Dinucleotide Phosphate Oxidases. Basic \& Clinical Pharmacology \& Toxicology, 110, 87-94.

11.R. J. Bloomer. T. M. Farney, J. F. Trepanowski, C. G. McCarthy, R. E. Canale, B. K. Schilling. (2010). Comparison of pre-workout nitric oxide stimulating dietary supplements on skeletal muscle oxygen saturation, blood nitrate/nitrite, lipid peroxidation, and upper body exercise performance in resistance trained men. Journal of the international society of sports nutrition, $7(16)$.

12.J. Mishra; R. K. Srivasatara, S.A. Shuklan and C,S. Raghan, (2007); Antioxidants in aromatic and medicinal plants, Modulating in vivo activity; Sci. Tech ; pp: 1-16.

13.J. Sedlak and R.H. Lindsay (1968). Analytical Biochemistry; 8: 192-205.

14.B.T. Kurien and R.H. Scofield (2003). Free radical mediated peroxidative damage in systemic lupus erythematosus. Life Sci,; 73(13):1655

15.S.Mohammed,I. Amin and Z. Sabri (2012).Nitric Oxide, Peroxynitrite and Malondialdehyde Levels as Markers for Nitrosative/Oxidative Stress in Iraqi Patients with Systemic Lupus Erythematosus. Iraqi $\mathbf{J}$ Pharm Sci, Vol.21(1).

16.M.A, El-Missiry, T.A, Fayed, M.R, ElSawy, A.A. El- Sayed (2007). Ameliorative effect of melatonin against gamma-irradiation-induced oxidative stress and tissue injury. Ecotoxicol Environ Saf 66: 278-286

17.P.A. Patil. T. Swami and K.R. Singh, (2009). Effect OF Atorvastati\& Simvastation Wound Healin In Albino Rats. Pharmacology online. JN Medical College. Karnataka, India. 2:963-974.

\section{How to cite this article:}

Zainab A. Hassan. 2016. Measuring Oxidative Balance for Athletes Body building abusers Nutritional Supplements in the City of Kirkuk, Iraq. Int.J.Curr.Res.Aca.Rev.4(2): 99-103. doi: http://dx.doi.org/10.20546/ijcrar.2016.402.012 